\title{
Motifs in East Java Traditional Batiks:
}

\author{
Cultural Visual Language
}

\author{
Ika Ismurdiyahwati* \\ Fine Arts Education Study Program \\ University PGRI Adi Buana Surabaya \\ Surabaya, Indonesia \\ *Ika@unipasby.ac.id
}

\author{
Atiqoh Nasor \\ Family Welfare Vocational Education Study \\ University PGRI Adi Buana Surabaya \\ Surabaya, Indonesia \\ atiqohnasor@gmail.com
}

\begin{abstract}
Batik and its traditional motifs imply cultural values. Various regions provide various motifs, thus, this research explores traditional batiks from Gresik, Lamongan, Tuban and Bojonegoro. This study is a qualitative research. The approach is cultural analysis, the data are collected by sampling, and the data analysis is analytical description. The result shows that Bandeng Loh motif from Gresik, Singo Mengkok from Lamongan, Lokcan and Gedog from Tuban, and Sekarjati and Jonegoroan from Bojonegoro contain cultural values and they are the most popular motifs of young people today.
\end{abstract}

Keywords-motif, consumer, creative, batik, young people

\section{INTRODUCTION}

Batik is the pride of Indonesia. Batik is the national icon of Indonesia [1]. Traditional Batik Nusantara, which comes from many regions and diversities, already has its own history. Therefore, tracing back the various motifs from various regions scattered throughout the Archipelago, is indispensably crucial. It provides a concept of the way of thinking of the indigenous tribes of each region. Ironically, many young generations mislead to understand the concept of motifs, for example, they do not understand the concept of motifs for the fabric of the corpse cover. Behind each motif, there must be a hidden meaning, even it is a toilet cover motif. Therefore, motifs in Batik of Nusantara must be interpretatively hyped for the better future for young generations. Moreover, the complex batikmaking process is less attractive to the younger generation [2]. This study with its tracing-back effort to the traditional old motifs purposes to traverse the historical meaning behind of the motifs up to the development of those motifs.

Motifs in Batik is an artwork that can be observed with a semiotic approach, or at least visual semiotics. As a knife of analysis, semiotics can be used to reveal the purpose of communicating any thoughts, feelings, or expressions. Art is a way of expression, communication, conveyance to the people through the composition of signs. Semiotics is a discipline that examines signs (including the meaning of symbols, indexes, icons) and works of art are the composition of signs both verbally and non-verbally [3]. In other word, art with its visual expression is a sort of visual language. It is a word that can be seen than read, an image that can be felt than seen. This research explores the fundamental research problems about the development of motifs that undergo changes and transformations, or even have disappeared because of time's fluctuation that rushes and races paradigm and perspectives.

Batik is a mirror that can be said as a culture of glorify (in accordance with the concept of the king of the god culture) with that view, would the concept of the King (god culture) still stand on these motifs at this time. Of course, it indicates that Batik implicitly infers the inseparable linkage with political elements and the recognition of government elitist [4]. Economically, regarding to trade, Batik represents an important export unique to Indonesia; it bears a national pride [5]. Thus, it cannot be naively taken aside that Batik is completely and extremely important for Indonesia in many aspects.

Moreover, defending Batik as Indonesia heritage is not that simple allegedly. It is not a surprise that relations between Indonesia and Malaysia are mostly characterized by diplomatic conventions and pleasantries [6]. These two countries seem to be judged with shared values, special relationship and common cultural traditions while all of which are ostensibly attached by the same racial and ethnic stock (in Bahasa it is called as serumpun). Malaysian politicians and its media particularly often give a sort of allusion for this familial bond because of its similar language, culture, and history. However, generally speaking, this bilateral tie, over the last decade, have been plunged in rivalry, rancor, and conflict. It is roasted by Malaysia's arrogant, cavalier, and big-headed conduct of Indonesian foreign workers and territorial disputes. Underlying these stiffness's, shared Indo-Malay cultural heritage and art forms increasingly overshadows all other aspects of the bilateral relationship [7]. Even in historical note, a Dutch textile printing company since 1846 used to produce Batik cloth for the West African consumer market [8]. Thus, can we be more aware with Batik and its historical tradition?

Batik for Nusantara is too valuable to describe. The uniqueness leans on its varieties. Nusantara has many cultures because of the plural ethnicities, tribes, cultures, and so on. A heritage has to be preserved. There's been a lot of preservation work going on. It is designed to make young people feel good about their own products, and the scale increases of the batik item itself. The preservation can be also practiced in online 
marketing to make this traditional heritage is reachable for young generation [9]. One of unique varieties is the north side of East java.

In the north side of East Java, there are some cities including Gresik, Lamongan, Tuban, and Bojonegoro. The touch of coastal regions makes the uniqueness of the artwork in the Batik. Conclusively speaking, this research sees strategies for developing new motifs and simultaneously for trending it to young generation.

\section{METHODS}

The research is about analysing the development of traditional batik motifs in the northern region of East Java province. The regions include traditional batik design from Gresik, Lamongan, Tuban, and Bojonegoro. It is a qualitative study in the field of fine art because it is phenomenologicalbased analysis. This research puts two-dimensional images of old batik motifs that still appear in the millennium era as the object of analysis. To interpret the data, this research uses linguistic studies, especially semiotics. The steps to analyse are data collection, classification and analysis. Through the analysis. To make it simple, just take a look at the diagram to see how this research works.

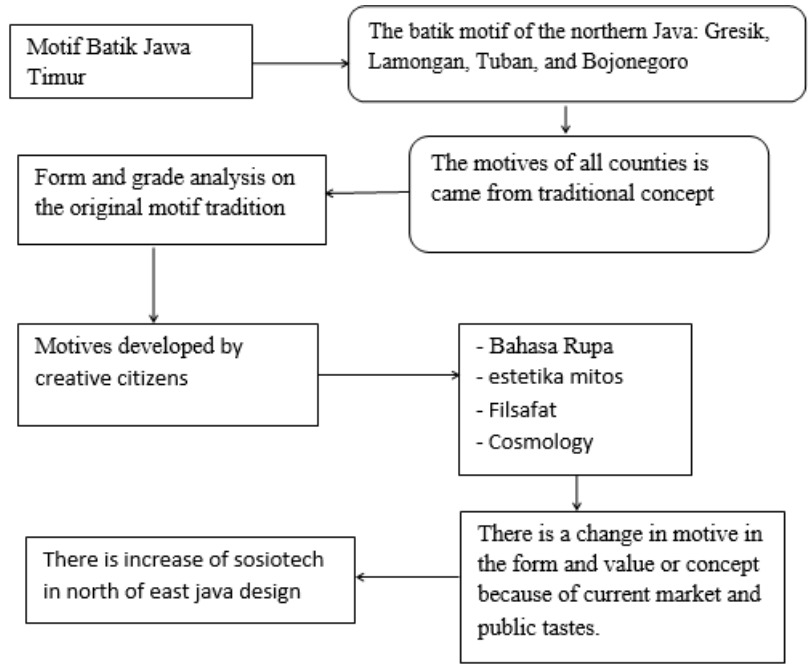

Fig. 1. Research flowchart.
Based on the figure 1, it can be known that Motifs of Batik in East Java (Gresik, Lamongan, Tuban, and Bojonegoro explore traditional concepts which are developed by creativity of the society, including visual language, myths, philosophy, and cosmology. These values can be integrated with the market demands. Therefore, culture and consumerism can be still in line relevantly.

\section{RESULTS AND DISCUSSION}

Gresik, Lamongan, Tuban, and Bojonegoro are the representative cities of the northern areas in East Java to be taken as the limitation of the Batiks in the analysis. The motifs are Bandeng Loh motif from Gresik, Singo Mengkok motif from Lamongan, Lokcan and Gedog motif from Tuban, and Sekarjati and Jonegoroan motif from Bojonegoro. Those are the most popular motifs of young people today. Before it strikes directly to the core of e of this analysis, it requires an understanding how the young generations look like because they are the subjects of this analysis.

Modern society is full of creative young generations. They represent today's life. They tend to be consumptive but also creative at the same time. They are well-connected to gadgets or smartphone and they are very familiar to use it. When it comes to their high capacity for technological use, they are also known as society of the network [10]. On the other hand, Smartphones are going to transform the culture, social life, technology landscape and other diverse aspects of modern society. From modernization to gadget, from process to instant. Society is full of rapidity, especially information. The abundant information changes the people's perspective to be more pragmatist which leads to capitalist society.

Sharing information can influence various processes and organizations, because information is part of human activity, and carries a great impact, because of its flexibility. It is in these societies that turn the market into a network with new tastes and impact on people's production, including centuriesold batik cloth. On traditional batik with sacred motifs is getting further eroded as global societies are organized in global finance through a universal network and information system. Let us look at the table 1 that are the result of traditional, slightly altered and even existing motifs, by modifying the basic ingredient. 
TABLE I. RESUlTs OF TRADITIONAL MotiFs

\begin{tabular}{|c|c|c|c|}
\hline No.1 & Motif Bandeng Loh, Gresik & Visual Language & Fabric Aesthetic \\
\hline & (2) & $\begin{array}{l}\text { Motive appears to be on the chase, with a } \\
\text { variety of positions in a single direction } \\
\text { that only the tail appears, with the sense of } \\
\text { movement. It's distortion and decorative }\end{array}$ & $\begin{array}{l}\text { These motifs do not exist vertical or } \\
\text { horizontal patterns. Therefore, not } \\
\text { part of the motifs resulting from } \\
\text { Indonesia's primordial thinking. So } \\
\text { this motive is the pure notion of } \\
\text { modern society today. }\end{array}$ \\
\hline 2. & engkok, Lamongan & Visual Language & Fabric Aesthetic \\
\hline & 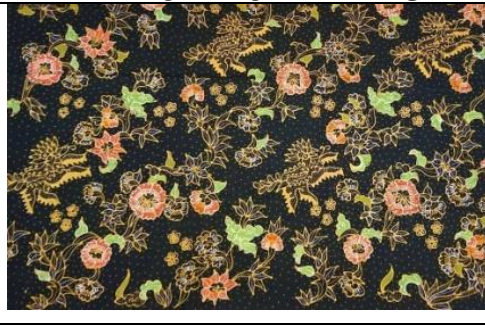 & $\begin{array}{l}\text { This motif is repeated splicing, in the form } \\
\text { of decorative stilling objects, composed of } \\
\text { depictions of lions in the form of plants, } \\
\text { flowers, leaves that propagate. The Angle } \\
\text { of the shot looked up, and the picture of } \\
\text { the single pattern, side by side, to be } \\
\text { related. }\end{array}$ & $\begin{array}{l}\text { This motif is found in the use of the } \\
\text { primordial pattern, all of the fabrics } \\
\text { is fulfilled. The concept of its } \\
\text { origins, the motive of its singo kok, } \\
\text { serves motifs of evil-revellen, to } \\
\text { those who use it, these motifs is } \\
\text { craetion of todays society, even still } \\
\text { follow the pattern of making } \\
\text { primodial concept of the living, prior } \\
\text { society }\end{array}$ \\
\hline 3. & Motif Lokcan, Batik Gedog, Tuban & Visual Language & Fabric Aesthetic \\
\hline & & $\begin{array}{l}\text { Lokcan's motive, batik gedog, the style of } \\
\text { its overhead description, which is the } \\
\text { Chinese lokcan bird feather, is in the form } \\
\text { of decorative stills and says more } \\
\text { important than smaller bird gestures. }\end{array}$ & $\begin{array}{l}\text { This motif is found in the use of the } \\
\text { primordial pattern of kacu (mandala) } \\
\text { concepts. Because of the repetition } \\
\text { of the picture pattern, all of the } \\
\text { fabric is fulfilled. Larger bird } \\
\text { feathers, surrounded by smaller } \\
\text { birds. The concept of making } \\
\text { Lokcan motive, forgetting symbols } \\
\text { of goodness and virtue and } \\
\text { excellence. These motifs, the pure } \\
\text { creations of the ancient rakes, which } \\
\text { are still dominated by today's } \\
\text { societies, so that this pattern survives } \\
\text { to this day. }\end{array}$ \\
\hline
\end{tabular}

We can finally explain further, that the fabric's motifs were different, as a result of their altered societies and distinct tastes. We've had a lot of previous studies discussing classic batik, especially from central Java, no longer known as classics, Karen was worn by anyone. Including the batik motifs found in the northern region of east Java, some were originally created for ceremonial symbols to help with developing market taste motifs. Virtualise have a profound influence on all forms of production because of globalized tissue thinking. As a result our local culture has been restricted collectively, because the market demands branding, because of the vulnerability to impersonation and the destruction of the creation process.

\section{CONCLUSION}

In this study, researchers can call for batik motif-motifs based on the changes that underlying existence. Such motifs, when examined as they were successfully analysed, have resulted in a successful early motive to be found in an old, damaged form, and the wearer was brought to the attention of sometimes subtle craftsmen. Changes that occur are poorly understood because of different ways of thinking. New motifs are the most marketable and well-liked and thus continue to be produced, until then new motifs of society's creative work adjust to market tastes.

\section{REFERENCES}

[1] E. Steelyana, "Batik, A Beautiful Cultural Heritage that Preserve Culture and Supporteconomic Development in Indonesia," Binus Bus. Rev., vol. 3, no. 1, p. 116, 2012.

[2] E. Eskak, "Mendorong Kreativitas Dan Cinta Batik Pada Generasi Muda Kritik Seni Karya Pemenang Lomba Desain Batik Bbkb 2012," Din. Kerajinan dan Batik, vol. 30, no. 1, pp. 1-10, 2013.

[3] R.A. Yelle, "Semiotics," in The Routledge Handbook of Research Methods in the Study of Religion, 2013.

[4] A.Y.P. Sartini, "Khasanah Batik Nusantara," Jantara, 2016.

[5] J.J. Fanina and F. Suaedi, "Challenges in preserving batik as indonesia's cultural identity facing global demand of sustainable eco-friendly fabric,"Vlakna a Text, 2020.

[6] I. Rachmawati, "Karakter Diplomasi Publik Indonesia terhadap Malaysia,” J. Hub. Int., vol. 6, no. 1, pp. 56-71, 2017. 
[7] M. Clark, "The politics of heritage: Indonesia-Malaysia cultural contestations," Indones. Malay World, vol. 41, no. 121, pp. 396-417, 2013.

[8] M. Hoogenboom, D. Bannink, and W. Trommel, "From local to grobal, and back," Bus. Hist., vol. 52, no. 6, pp. 932-954, 2010.
[9] H. Himawan, A. Saefullah, and S. Santoso, "Analisa dan Perancangan Sistem Informasi Penjualan Online (E-Commerce) pada CV Selaras Batik Menggunakan Analisis Deskriptif," Sci. J. Informatics, vol. 1, no. 1, pp. 53-63, 2015.

[10] M. Sarwar and T.R. Soomro, "Impact of Smart Phones on Society," Eur. J. Sci. Res., vol. 98, no. 2, pp. 216-226, 2013. 